\title{
Immunostimulant as an adjuvant therapy on Toll-like receptor concentration in children with acute otitis media
}

\author{
Ashraf S. El Hamshary', Hesham A. Abdel Rahman', Mohamed Aboelsoued², Rasha A. Elsayed ${ }^{3}$ and \\ Abdelhakim F. Elwany ${ }^{1 *}$
}

\begin{abstract}
Background: Acute otitis media (AOM) is the commonest pediatric bacterial infection, affecting up to $75 \%$ of children at some time before age 5 years. AOM is among the primary reasons for antibiotic prescriptions in pediatric outpatients. This study aimed to detect the value of immunostimulant as an adjuvant therapy with antibiotics for treatment of acute otitis media in children. This study included 60 children suffering from acute otitis media; their age ranged from 3 to 5 years during the period from May 2018 to March 2019. The patients in this study were divided into 2 groups: group A included 30 patients with AOM who received amoxicillin and clavulanic acid antibiotic at attack of AOM. Group B included 30 patients with AOM who received the same antibiotic with immunostimulant (Echinacea extract) for 3 months. Samples of blood were taken from all patients to detect the level of Toll-like receptor by real-time PCR, before and after 3 months of antibiotic and immunostimulant therapy. All cases underwent assessment including complete history taking, otoscopic examination of the ear, and blood sample to detect the level of Toll-like receptor (TLR) before and after the therapy by real-time PCR.

Results: There was a significant $(P<0.05)$ decrease in the TLR2 expression in antibiotic-treated patients than its expression before treatment. On the other hand, there was a significant $(P<0.05)$ increase in the TLR2 expression in immunostimulant plus antibiotic-treated patients than its expression before treatment; there was a high significant $(P<0.001)$ increase in the expression of TLR2 in the immunostimulant plus antibiotic than the antibiotictreated patients.
\end{abstract}

Conclusion: The role of antibiotics against bacterial infection causing acute otitis media can be enhanced by immunostimulant which increases the expression of Toll-like receptors which play a major role stimulating immune system to resist bacterial infection.

\section{Background}

Otitis media is the inflammation of the mucous membrane of the middle ear cleft. It is one of the most common infectious diseases of childhood worldwide. Two out of three children will have at least one episode of otitis media before their third birthday. Varying prevalence rates of otitis media have been documented from

\footnotetext{
* Correspondence: hakim_ent@yahoo.com

'Department of Otorhinolaryngiology, Faculty of Medicine, Benha University, Benha, Egypt

Full list of author information is available at the end of the article
}

various parts of the world. Infants and young children are at the highest risk of developing otitis media, with peak prevalence between 6 and 36 months of age. It is particularly prevalent among children with cleft palate and other craniofacial defects, and those from lower socio-economic status [1].

Bacteria have remained the most important etiological agents in suppurative or discharging otitis media. Resistance to multiple antibiotics is not uncommon, further predisposing to complications among affected children [2].

\section{Springer Open}

(c) The Author(s). 2020 Open Access This article is licensed under a Creative Commons Attribution 4.0 International License, which permits use, sharing, adaptation, distribution and reproduction in any medium or format, as long as you give appropriate credit to the original author(s) and the source, provide a link to the Creative Commons licence, and indicate if changes were made. The images or other third party material in this article are included in the article's Creative Commons licence, unless indicated otherwise in a credit line to the material. If material is not included in the article's Creative Commons licence and your intended use is not permitted by statutory regulation or exceeds the permitted use, you will need to obtain permission directly from the copyright holder. To view a copy of this licence, visit http://creativecommons.org/licenses/by/4.0/. 
The most common bacteria responsible for AOM have been Streptococcus pneumoniae in 27-52\%, Haemophilus influenzae in 16-52\%, and Moraxella catarrhalis in $2-15 \%$ of episodes. The proportion of these bacteria has been relatively constant in recent years. The most notable changes in data collected from 1980 to 1989 in 2807 children in the USA were an increase in the prevalence of $S$. pneumoniae and a rise in the beta-lactamase-producing strains of $H$. influenzae and M. catarrhalis [3].

Other pathogens include Staphylococcus aureus, Streptococcus pyogenes, Pseudomonas aeruginosa, Klebsiella, Escherichia coli, and as a new pathogen Alloiococcus otitidis, all at a proportion of a few percent [4].

A human Toll homolog or human TLRs were then identified and found to induce cytokine production and expression of costimulatory molecules. To date, 12 members of the TLR family have been identified in mammals. TLRs are type 1 integral membrane glycoproteins characterized by the extracellular domains containing varying numbers of leucine-rich repeat (LRR) motifs and a cytoplasmic signaling domain homologous to that of the interleukin 1 receptor (IL-1R) [5].

TLRs can be further divided into several subfamilies, each of which recognizes related PAMPs: the subfamily of TLR1, TLR2, and TLR6 recognize lipids, whereas the highly related TLR7, TLR8, and TLR9 recognize nucleic acids. However, the TLRs are unusual in that some can recognize several structurally unrelated ligands [6].

Amoxicillin is the drug of choice if antibiotics are required, amoxicillin-clavulanate should be considered if there is concurrent purulent conjunctivitis, a history of amoxicillin treatment within the previous 30 days, relapse of a recent infection, or nonresponse to amoxicillin. Consider a second-generation (cefprozil or cefuroxime) or third-generation cephalosporin if the child has a nonsevere allergic reaction to amoxicillin or penicillin [7].

Echinacea may be beneficial for individuals who already have an immune disorder but that it has little or no effect on a healthy immune system. The use of immunostimulants in the prevention of the upper respiratory tract infection is controversial [8].

The aim of this study was to detect the value of immunostimulant as an adjuvant therapy with antibiotics for treatment of acute otitis media in children.

\section{Methods}

\section{Patients}

This study was carried out in the period from May 2018 to March 2019 and included children suffering from acute otitis media presented to the outpatient clinic of the University Hospital; their age ranged from 3 to 5 years. Sixty patients were included in the study, and they were divided into two groups: group A included 30 patients with AOM who received amoxicillin and clavulanic acid antibiotic $45 \mathrm{mg} / \mathrm{kg} /$ day every $12 \mathrm{~h}$ for 10 days at the attack of AOM. Group B included 30 patients with AOM who received the same antibiotic at the attack of AOM with immunostimulant (Echinacea extract) in a dose of 2 teaspoonfuls three times daily for 3 months. Informed written consents were obtained from parents of all patients who participated in this study.

Inclusion criteria include acute otitis media (acute onset of symptoms and signs, Bulging drum, congestion, and suppuration), absence of any systemic disease, and no previous ear surgery.

Exclusion criteria include previous perforation in the same ear and patients needing adenotonsillectomy.

\section{First visit assessment}

All sixty patients were subjected to history taking, clinical examination, otoscopic examination of the ear, and blood investigations. Samples of blood were obtained from all patients to measure the level of Toll-like receptor by real-time PCR.

\section{Treatment data}

All patients were on amoxicillin and clavulanic acid (45 $\mathrm{mg} / \mathrm{kg} /$ day every $12 \mathrm{~h}$ ) for 10 days at time of attack during the period of 3 months. All cases of group B were on immunostimulant (Echinacea extract) in a dose of 2 teaspoonfuls three times daily for 3 months in addition to the same antibiotic.

Echinacea purpurea (Asteraceae) is a perennial medicinal herb with important immunostimulatory and anti-inflammatory properties, especially the alleviation of cold symptoms. The plant also attracted scientists' attention to assess other aspects of its beneficial effects. For instance, antianxiety, antidepression, cytotoxicity, and antimutagenicity as induced by the plant have been revealed in various studies. The findings of the clinical trials are controversial in terms of side effects. While some studies revealed the beneficial effects of the plant on the patients and no severe adverse effects, some others have reported serious side effects including abdominal pain, angioedema, dyspnea, nausea, pruritus, rash, erythema, and urticaria. Other biological activities of the plant such as antioxidant, antibacterial, antiviral, and larvicidal activities have been reported in previous experimental studies [9].

\section{Post-treatment assessment}

All cases underwent assessment including complete history taking, otoscopic examination of the ear, and blood sample to detect the level of Toll-like receptor by realtime PCR. 
Samples of blood were obtained from all patients to detect the level of Toll-like receptor by real-time PCR.

\section{Blood sample collection}

Venous blood samples $(3 \mathrm{ml})$ were collected from patients in the 1st visit and after 3 months of medical treatment under complete aseptic conditions in EDTAcontaining tubes; blood was used for RNA extraction, and the extracted RNA was stored at $-80{ }^{\circ} \mathrm{C}$ until the analysis of TLR 2 gene.

\section{Detection of level of TLR 2 gene by PCR}

PCR is a test for in vitro amplification of specific RNA sequences using two primers that hybridize to opposite strands and flank target RNA region. Sequences flanking TLR 2 polymorphism were PCR-amplified from genomic RNA using a pair of specific primers; the amplified products were then analyzed by electrophoresis.

\section{Protocol of extraction of genomic RNA from peripheral blood leucocytes}

It was done as described by the manufacturer (Thermo Scientific): $50-500 \mu \mathrm{l}$ of blood was centrifugated for 5 $\min$ at $4{ }^{\circ} \mathrm{C}$, and the supernatant was discarded. The pellet was resuspended in $600 \mu \mathrm{l}$ of lysis puffer, mixed well by vortexing, and then $450 \mu \mathrm{l}$ of ethanol (96-100\%) was added, mixed by pipetting or vortexing. Half of the prepared lysate was transferred to a column inserted in a collection tube; the column was centrifugated for $1 \mathrm{~min}$ at $12,000 \times g(11,000 \mathrm{rpm})$, the flow-through solution discarded, and the column and collection tube reassembled. Then, the remaining lysate was transferred into the column and centrifugated as before, the collection tube containing the flow-through solution was discarded, and the column was placed into a new 2-ml collection tube. Seven hundred microliters of wash buffer WB 1 (with ethanol added) was added and centrifugated for $1 \mathrm{~min}$ at $12,000 \times g(11,000 \mathrm{rpm})$, flow-through discarded, and the purification column placed back into the collection tube. Five hundred microliters of wash buffer 2 (with ethanol added) was added to the purification column and centrifugated for $1 \mathrm{~min}$ at $12,000 \times g(11,000 \mathrm{rpm})$. Five hundred microliters of wash buffer 2 (with ethanol added) was added to the purification column, centrifugated for $2 \mathrm{~min}$ at $12,000 \times g(11,000 \mathrm{rpm})$, the collection tube containing the flow-through solution discarded, and the purification column transferred to RNase-free $1.5 \mathrm{ml}$ microcentrifuge tube. Fifty microliters of nuclease-free water was added to the center of purification column membrane and centrifugated for $1 \mathrm{~min}$ at $12,000 \times \mathrm{g}$ (11, $000 \mathrm{rpm})$. The purification column was discarded, and the purified RNA was used immediately in downstream applications and kept the RNA on ice after extraction.

\section{Steps of CDNA by process of reverse transcriptase}

The protocol was done using Maxime RT PreMix kit. Template RNA $(5 \mu \mathrm{l})$ and distilled water $(15 \mu \mathrm{l})$ were added to the Maxime RT Premix tubes to a total volume of $20 \mu \mathrm{l}$. The clear pellet was dissolved by pipetting. Then, the cDNA synthesis reaction was performed using PCR machine. The reactant was diluted by adding $20-$ $50 \mu \mathrm{l}$ of sterile water into the tube containing the cDNA obtained at RT reactant. PCR reaction was proceeded.

\section{Gene amplification using PCR}

TLR2 gene was amplified using PCR with forward primer: (5'd 5'-GCC AAA GTC TTG ATT GAT TGG-' $\left.3^{\prime}\right)$ and reverse primer: (5' ${ }^{\prime}$ TTG AAG TTC TCC AGC TCC TG-3'). The amplification was carried out in realtime PCR instrument (Step One-Applied Biosystems). The following components were added to each $20 \mu \mathrm{l}$ reaction tube at room temperature: $2 \mu \mathrm{l}$ cDNA template, $6 \mu \mathrm{l}$ nuclease-free water, $10 \mu \mathrm{l}$ HERA SYBRqPCR kit lo, Hi\&No (wf1030400x), forward primer $1 \mu$ l reverse primer, and $6 \mu \mathrm{l}$ nuclease-free water. The PCR reaction mixture was mixed well. The PCR reaction tubes were closed and placed inside real-time PCR instrument (Step One-Applied Biosystems $s^{\circ}$ ). The run method of PCR is initial denaturation at $95^{\circ} \mathrm{C}$ for $2 \mathrm{~min}$, followed by $40 \mathrm{cy}$ cles of denaturation at $95^{\circ} \mathrm{C}$ for $10 \mathrm{~s}$ then annealing at $51^{\circ} \mathrm{C}$ for $1 \mathrm{~min}$, and finally melting at $95^{\circ} \mathrm{C}$ for $15 \mathrm{~s}$, $60^{\circ} \mathrm{C}$ for $1 \mathrm{~min}$, and $95^{\circ} \mathrm{C}$ for $15 \mathrm{~s}$.

\section{Results}

\section{Study population characteristics}

In the present study, 60 children suffering from acute otitis media presented to the outpatient clinic of University Hospital. Their age ranged from 3 to 5 years. The patients in this study were divided into 2 groups: group A included 30 patients with AOM who received amoxicillin and clavulanic acid antibiotic $45 \mathrm{mg} / \mathrm{kg} /$ day every $12 \mathrm{~h}$ for 10 days. Group B included 30 patients with AOM who received the same antibiotic with immunostimulant (Echinacea extract) in a dose of 2 teaspoonfuls three times daily for 3 months for a total of 60 subjects.

There was a significant $(P<0.05)$ decrease in the TLR2 expression in antibiotic-treated patients than its expression before treatment (Table 1). On the other hand, there was a significant $(P<0.05)$ increase in the

Table 1 TLR2 expression in patient groups before and after treatment by antibiotic

\begin{tabular}{|c|c|c|c|}
\hline \multirow[t]{3}{*}{ Parameter } & \multicolumn{2}{|l|}{ Patient group } & \multirow{3}{*}{$\begin{array}{l}P \\
\text { value }\end{array}$} \\
\hline & \multicolumn{2}{|c|}{ Group A (antibiotic) } & \\
\hline & Before treatment & $\overline{\text { After treatment }}$ & \\
\hline TLR2 expression & $27.33 \pm 1.58^{*}$ & $26.30 \pm 2.2$ & $<0.05$ \\
\hline
\end{tabular}


TLR2 expression in immunostimulant plus antibiotictreated patients than its expression before treatment (Table 2). As shown in Table 3, there was a high significant $(P<0.001)$ increase in TLR expression in the immunostimulant plus antibiotic than the antibiotictreated patients.

\section{Discussion}

Acute otitis media is the most frequent upper respiratory tract infection in pediatric patients. It is the main cause of medical visits or consultations, use of antibiotics, and ambulatory surgeries in developed countries. Acute otitis media is an infection of the middle ear with an acute clinical onset of effusion and inflammation signs and symptoms, such as fever, irritability, otalgia, and otorrhea. Many cell types, particularly those which interact with the external environment, express innate immune receptors, including the TLRs. TLRs are found on or within surface epithelial cells, mast cells, and dendritic cells and are prominent at mucosal surfaces such as that lining in the middle ear [10].

Our study revealed that TLR2 expression was about 3fold higher in the immunostimulant plus antibiotictreated patients in comparison with the patients treated with antibiotic only. This difference in TLR2 expression might be due to the induction of TLRs by the immunostimulant.

Han et al. [11] examined the role of TLR2 in host defense against Streptococcus pneumoniae infection in the middle ear between wild-type and TLR 2-deficient mice by inoculation of Streptococcus pneumonia through the tympanic membrane. About half of TLR 2-deficient mice died compared to only $12 \%$ of wild-type mice. TLR2-deficient mice may produce relatively low levels of proinflammatory cytokines following pneumococcal challenge, thus hindering the clearance of bacteria from the middle ear and leading to sepsis and a high mortality rate. This study provided evidence that TLR2 might be important in the molecular pathogenesis and host response to otitis media. In a similar study, Hirano et al. [12] inoculated non-typeable Haemophilus influenzae (NTHi) through the tympanic membrane of mice which were divided to wild-type and TLR4-deficient mice and found that bacterial counts of NTHi in wild-type mice showed significantly lower bacterial count after $24 \mathrm{~h}$

Table 2 TLR2 expression in patient groups before and after treatment by immunostimulant plus antibiotic

\begin{tabular}{llll}
\hline Parameter & \multicolumn{2}{l}{ Patient group } & $P$ \\
\cline { 2 - 2 } & Group B (immunostimulant and antibiotic) & \\
\cline { 2 - 2 } & Before treatment & After treatment & \\
\hline TLR2 expression & $27.07 \pm 1.85$ & $28.71 \pm 1.7^{*}$ & $<0.05$ \\
\hline $\begin{array}{l}\text { Data are expressed by means standard deviation (SD) } \\
* P<0.05 \text { : significant }\end{array}$ &
\end{tabular}

than TLR4-deficient mice $(P<0.01)$, and the bacterial counts were almost negligible $72 \mathrm{~h}$ after injection. In TLR4-deficient mice, bacterial counts continued to increase significantly even at $72 \mathrm{~h}$ after injection.

Several studies reported the relation between the TLR levels and immune response. Kaur et al. [13], as they collected middle ear fluid by tympanocentesis from 66 children aged from 6 to 30 months suffering from acute otitis media, for culture and measuring the level of cytokines, chemokines, and Toll-like receptor expression by real-time PCR, found that 42 of these middle ear fluid cultures were positive for a common bacterial otopathogens (Streptococcus pneumoniae, NTHi, and Moraxella catarrhalis) and 24 middle ear fluid samples were culture negative, and they found that culture-positive MEF had higher levels of all cytokines and chemokines (9300-fold) as compared to MEF that was culture negative. PCR-positive/culture-negative MEF for otopathogens showed significant differences $(P<0.01)$ in TLR2, TLR4, and TLR9 expression (6-31-fold), but cytokine and chemokine levels were similar compared to PCR-negative/ culture-negative MEF. No significant differences were found in the cytokine/chemokine/TLR levels among the bacterial otopathogen species.

On the other hand, Lee et al. [14] disagreed with the result of this study, when he collected middle ear fluids from 96 pediatric patients who underwent ventilation tube insertion for the treatment of otitis media with effusion. Of these 96 children, 24 had been treated more than four times within the previous year or more than three times within the previous 6 months and were categorized as the otitis-prone group, whereas the other 72 children constituted the non-otitis-prone group; the 67 fluids examined (69.8\%) were apparently sterile, whereas bacteria grew from the remaining 29 samples (30.2\%). The expression of the TLR, cytokine, and NOS mRNAs in the effusion fluid of both the otitis-prone and nonotitis-prone groups was measured after amplification by real-time PCR. The TLR, cytokine, and NOS expression levels were significantly lower in the otitis-prone than in the non-otitis-prone group $(P<0.05)$. Although higher levels of TLR, cytokine, and NOS mRNAs were generally observed in culture-positive than in culture-negative patients, none of these differences was statistically significant and no differences were observed in the expressions relative to the frequencies of ventilation tube insertion. Also, they suggested that decreased expression of TLRs might be associated with increased susceptibility to OME.

Several studies demonstrated improvement in the severity and duration of the common cold in adults treated with Echinacea products. Vimalanathan et al. [15] studied the role of Echinacea purpurea in the regulation of surface receptor expression in human bronchial 
Table 3 TLR2 expression in patient groups before and after treatment by antibiotic and immunostimulant plus antibiotic

\begin{tabular}{llllll}
\hline Parameter & \multicolumn{2}{l}{ Patient group } & & \\
\cline { 2 - 2 } & \multicolumn{1}{l}{ Group A } & & Group B & \\
\cline { 2 - 3 } & Before treatment & After treatment & & Before treatment & After treatment \\
\hline TLR2 expression & $27.33 \pm 1.58^{\mathrm{b}}$ & $26.30 \pm 2.2^{\mathrm{c}}$ & & $27.07 \pm 1.85^{\mathrm{bc}}$ & $28.71 \pm 1.7^{\mathrm{a}}$
\end{tabular}

Data are expressed by means \pm standard deviation (SD). Means followed by different letters indicated significance. $P<0.001$ : highly significant

TLR2 Toll-like receptor 2 , group $A$ antibiotic treatment, group $B$ immunostimulant and antibiotic treatment

epithelial cells during influenza virus-induced bacterial super-infection. An in vitro study used tissue culture technique and found that Influenza virus A (H3N2) is a major pathogen that causes secondary bacterial infection and inflammation that leads to pneumonia. H3N2 increased the adhesion of live NTHi significantly by 3.08 -fold compared to control cells $(P<0.01)$. Virusinfected cells that were incubated with Echinacea showed significantly reduced adhesion of NTHi from 3.08 -fold to 0.55 -fold. In addition, both flow cytometry and confocal microscopy staining confirmed that infection with the influenza virus induced TLR-4 expression and that Echinacea downregulated virus-induced TLR4 expression; however, it was not statistically significant. These results indicated that E. purpurea had the potential to reduce the risk of respiratory complications by preventing virus-induced bacterial adhesion and through the inhibition of inflammation super-stimulation (cytokine storms).

\section{Conclusion}

Acute otitis media is one of the most common infectious diseases of childhood worldwide, which needs medical treatment to cure this condition to prevent complications such as chronic state; the innate immune system is considered the first line of defense during the host response to pathogens.

The role of antibiotics against bacterial infection causing acute otitis media can be enhanced by immunostimulant which increases the expression of Toll-like receptors which play a major role in stimulating the immune system to resist bacterial infection.

\section{Abbreviations}

AOM: Acute otitis media; TLR: Toll-like receptor

\section{Acknowledgements}

Not applicable.

\section{Authors' contributions}

ASEH and HAAR designed the study and assisted all over the study. MA and AFE contributed to the sample collection, dose preparations, treatments, laboratory work analysis, statistics, data interpretation, and manuscript preparation. RAE shared in the laboratory work analysis and detection of TLR2 gene by PCR. All authors shared in the manuscript preparation and have read and approved the final manuscript.

\section{Funding}

None.
Availability of data and materials

All data generated or analyzed during this study are included in this published article.

\section{Ethics approval and consent to participate}

This study was approved by the Research Ethics Committee of Faculty of Medicine, Benha University (REC-FOMBU), Egypt (10 April 2018). The experiments were conducted according to the international guidelines including the Declaration of Helsinki (DoH), Islamic Organization for Medical Sciences (IOMS), the WHO, and International Council on Harmonization and Good Clinical Practice (ICHGCP). An informed written consents were obtained from parents of all patients who participated in this study.

\section{Consent for publication}

Not applicable.

\section{Competing interests}

The authors declare that they have no competing interests.

\section{Author details}

'Department of Otorhinolaryngiology, Faculty of Medicine, Benha University, Benha, Egypt. ${ }^{2}$ Hearing and Speech Institute, Cairo, Egypt. ${ }^{3}$ Department of Medical Microbiology and Immunology, Faculty of Medicine, Benha University, Benha, Egypt.

Received: 21 May 2020 Accepted: 19 June 2020

Published online: 23 September 2020

\section{References}

1. Wasson JD, Yung MW (2015) Evidence-based management of otitis media: a 5 S model approach. J Laryngol Otol 129(2):112-119

2. Lieberthal AS, Carroll AE, Chonmaitree T, Ganiats TG, Hoberman A, Jackson MA, Joffe MD, Miller DT, Rosenfeld RM, Sevilla XD, Schwartz RH, Thomas PA, Tunkel DE (2013) The diagnosis and management of acute otitis media. Pediatrics. 131(3):e964-e999

3. Emmett SD, Kokesh J, Kaylie D (2018) Chronic ear disease. Med Clin North Am 102(6):1063-1079

4. Qureishi A, Lee Y, Belfield K, Birchall JP, Daniel M (2014) Update on otitis media - prevention and treatment. Infect Drug Resist 7:15-24

5. Toussi D, Massari $P$ (2014) Immune adjuvant effect of molecularly-defined toll-like receptor ligands. Vaccines 2(2):323-353

6. Peana M, Zdyb K, Medici S, Pelucelli A, Simula G, Gumienna-Kontecka E, Zoroddu MA (2017) Ni(II) interaction with a peptide model of the human TLR4 ectodomain. J Trace Elem Med Biol 44:151-160

7. Wichtl M (2004) Herbal drugs and phytopharmaceuticals: a handbook for practice on a scientific basis (No. Ed. 3). Medpharm GmbH Scientific Publishers

8. Karsch-Völk M, Barrett B, Kiefer D, Bauer R, Ardjomand-Woelkart K, Linde K (2014) Echinacea for preventing and treating the common cold. Cochrane Database Syst Rev 2

9. Goey AK, Rosing H, Meijerman I, Sparidans RW, Schellens JH, Beijnen JH (2012) The bioanalysis of the major Echinacea purpurea constituents dodeca-2E, 4E, 8Z, 10E/Z-tetraenoic acid isobutylamides in human plasma using LC-MS/MS. J Chromatogr B 902:151-156

10. Leichtle A, Lai Y, Wollenberg B, Wasserman SI, Ryan AF (2011) Innate signaling in otitis media: pathogenesis and recovery. Curr Allergy Asthma Rep 11(1):78-84

11. Han F, Yu H, Tian C, Li S, Jacobs MR, Benedict-Alderfer C, Zheng QY (2009) Role for Toll-like receptor 2 in the immune response to Streptococcus pneumoniae infection in mouse otitis media. Infect Immun 77(7):3100-3108 
12. Hirano T, Kodama S, Fujita K, Maeda K, Suzuki M (2007) Role of Toll-like receptor 4 in innate immune responses in a mouse model of acute otitis media. FEMS Immunol Med Microbiol 49:75-83

13. Kaur R, Casey J, Pichichero M (2015) Cytokine, chemokine, and toll-like receptor expression in middle ear fluids of children with acute otitis media. Laryngoscope 125:E39-E44

14. Lee HY, Chung JH, Lee SK, Byun JY, Kim YI, Yeo SG (2013) Toll-like receptors, cytokines \& nitric oxide synthase in patients with otitis media with effusion. Indian J Med Res 138(October):523-530

15. Vimalanathan S, Schoop R, Suter A, Hudson J (2017) Prevention of influenza virus induced bacterial super infection by standardized Echinacea purpurea, via regulation of surface receptor expression in human bronchial epithelial cells. Virus Res 233:51-59

\section{Publisher's Note}

Springer Nature remains neutral with regard to jurisdictional claims in published maps and institutional affiliations.

\section{Submit your manuscript to a SpringerOpen ${ }^{\circ}$ journal and benefit from:}

- Convenient online submission

- Rigorous peer review

- Open access: articles freely available online

High visibility within the field

- Retaining the copyright to your article

Submit your next manuscript at $\boldsymbol{\nabla}$ springeropen.com 